\title{
River flow is critical for vegetation dynamics: Lessons from multi-scale analysis in a hyper-arid endorheic basin
}

\author{
Qin Shen ${ }^{\mathrm{a}}$, Guangyao Gao ${ }^{\mathrm{a}, \mathrm{b}, *}$, Yihe Lü ${ }^{\mathrm{a}, \mathrm{b}}$, Shuai Wang ${ }^{\mathrm{a}, \mathrm{b}}$, Xiaohui Jiang ${ }^{\mathrm{c}}$, Bojie Fu ${ }^{\mathrm{a}, \mathrm{b}}$ \\ a State Key Laboratory of Urban and Regional Ecology, Research Center for Eco-Environmental Sciences, Chinese Academy of Sciences, Beijing 100085, China \\ b Joint Center for Global Change Studies, Beijing 100875, China \\ c College of Urban and Environmental Sciences, Northwest University, Xi'an 710027, China
}

\section{H I G H L I G H T S}

- The spatio-temporal variations and influential factors of vegetation cover in a hyper-arid endorheic basin were studied.

- NDVI and hydro-climatic factors showed different relationships at catchment and pixel scales.

- The river flow mainly affected the vegetation cover within $2 \mathrm{~km}$ distance and had a 1-yr lag effect.

- The water diversion project should be adjusted based on spatio-temporal lagged hydro-ecological connections.

\section{A R T I C L E I N F O}

\section{Article history:}

Received 3 April 2017

Received in revised form 9 June 2017

Accepted 10 June 2017

Available online 23 June 2017

Editor: Elena PAOLETTI

\section{Keywords:}

Vegetation cover

Desert riparian vegetation

River flow

Groundwater

Heihe River Basin

\section{GRAPHICALA B STRACT}
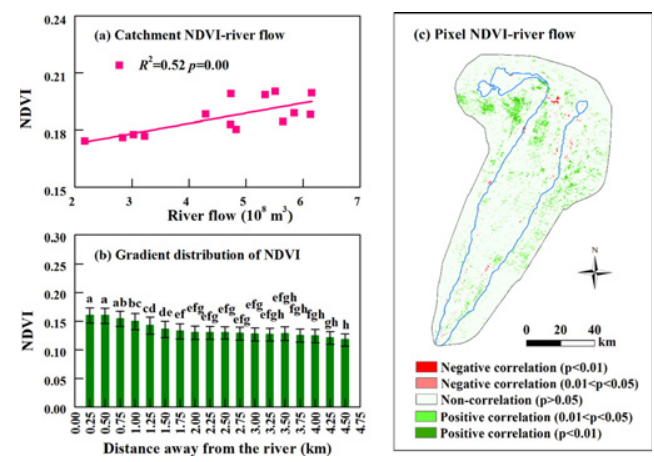

\section{A B S T R A C T}

Knowledge of the spatio-temporal responses of vegetation dynamics to hydro-climatic factors is important to assess ecological restoration efforts in arid and semiarid areas. In this study, the vegetation dynamics during 20002015 were investigated in the downstream area of the Heihe River Basin (HRB) in Northwest China where an ecological water diversion project (EWDP) commenced in 2000. The spatio-temporal relationships between vegetation cover and climatic factors (precipitation and temperature) and available water resources (river flow and groundwater) were determined. The results indicated that the mean growing season NDVI increased significantly during the period of 2000-2015, and the area of East Juyan Lake (EJL) enlarged to $36.4 \mathrm{~km}^{2}$ in 2010 . The scale effect of the relationships between NDVI and hydro-climatic factors was obvious. At the catchment scale, changes of NDVI were not significantly correlated with climatic factors, but significantly related with the antecedent 1year river flow. River flow played an important role in vegetation growth within approximately $2000 \mathrm{~m}$ distance from the river bank. At the pixel scale, the changes of NDVI were significantly positive with temperature and river flow in $17.40 \%$ and $7.14 \%$ of the study area, respectively, whereas significant relationship between NDVI and precipitation occurred in only $0.65 \%$ of study area. The suitable water table depth for vegetation growth was between 1.8 and $3.5 \mathrm{~m}$. The increased river flow and recovered groundwater due to the EWDP were critical for the improvement of vegetation cover, whereas the riparian vegetation degraded along some parts of the river bank. It is important to improve integrated watershed management with consideration of spatio-temporal lagged hydro-ecological connections in the study area.

(c) 2017 Elsevier B.V. All rights reserved.

\footnotetext{
* Corresponding author.

E-mail address: gygao@rcees.ac.cn (G. Gao).
} 
The shortage of water resources makes arid and semiarid ecosystems the most susceptible biomes to land degradation and global climate change (James et al., 2013). Ecological restoration of degraded arid and semiarid ecosystems has received much attention worldwide due to the accelerated desiccation, salinization and groundwater degradation (King, 2011). Natural vegetation in arid and semiarid regions acts an important role in biodiversity conservation and desertification reduction. Vegetation growth is strongly influenced by climate change, and it is more sensitive to climate droughts in drier regions than wetter regions (Zhang et al., 2016). Air temperature and precipitation are two critical climatic factors, and have been widely considered as the important influencing factors of vegetation growth. Higher temperatures associated with deficiency of precipitation had negative consequences on plant growth, especially in semi-arid ecosystems (Lotsch et al., 2005). However, shallow groundwater replenished by snowmelt in the form of river flow was critical for natural oases to maintain much higher productivity with respect to the other ecosystems supported by local rainfall in arid regions (Jobbagy et al., 2011). Severe reduction in river flow resulted in notable degradation of riparian vegetation while the increase of extreme rainfall could benefit hydrological connectivity between river flow and surrounding floodplains (Fernandes et al., 2016). Furthermore, human activities have an important effect on riparian ecosystems. Major human activities include alteration of river flow through dam construction and groundwater withdrawal, urbanization, and modification of biotic conditions through agriculture, grazing and introduction of non-native species (Patten, 1998).

In the arid and semiarid endorheic basin, the contradiction between enlarged irrigated agriculture in the midstream area and degraded natural ecosystem in the downstream area has become increasingly prominent (Schlüter et al., 2005; He et al., 2012). Greater consumption of water in the midstream area implies less available water in the downstream area, i.e., human activities in the midstream area benefit at the expense of degradation in downstream area. Therefore, it was a critical issue to determine the optimal level of water diversion between midstream and downstream areas in the endorheic basin (Barbier, 2003). The responses of ecosystem in the downstream area to river flow regulation caused by water diversion from the midstream involve many complex hydrological processes (Zhao et al., 2016). Understanding the vegetation change before and after water diversion, and investigating the hydrological linkages between midstream and downstream areas are essential for water resources planning in endorheic basins (Nepal et al., 2014). Many pre-date readily available remotely sensed data provided important approaches for analysis of vegetation change before and after water diversion to better reallocate limited water resources for ecosystem conservation or restoration in arid and semiarid regions, such as the Central Asia (Imentai et al., 2015) and Northwestern China (Cheng et al., 2014; Zhu et al., 2016).

The Heihe River is the second largest endorheic rivers in Northwestern China. With the population expansion and the rapid economic development in the upper and mid-catchment of the Heihe River Basin (HRB), water consumption increased rapidly and the water available for ecological processes was reduced. A series of severe ecological disasters appeared, for example, the dry up of terminal lakes including the East Juyan Lake (EJL) and West Juyan Lake (WJL), the death of desert riparian vegetation and the frequent occurrence of sandstorms (Cheng et al., 2014). In order to restore the degraded ecosystem, the Chinese government carried out an ecological water diversion project (EWDP) since 2000 to reduce river flow consumption for irrigation in the midcatchment, and more water has been delivered from the midstream to the downstream area of the HRB. However, more water has been used for the development of economy in the downstream area of HRB, including the expansion of the cultivated land and tourism. In this way, the ecological water was squeezed by economic water. Therefore, the ecological water used by natural oases should be evaluated, and the core task was to understand the responses of vegetation dynamics to water resource availability at varying temporal and spatial scales, which made it possible to assess ecological restoration effect of the EWDP. Previous studies about the vegetation dynamics in the downstream area of HRB usually concentrated on single respect, such as the relationship between NDVI and river flow (Jin et al., 2010; Zhao et al., 2016), and that between NDVI and groundwater (Wang et al., 2011; Zhu et al., 2012). The spatio-temporal patterns and influencing factors of vegetation dynamics needed further investigation. In this study, the relationship between vegetation dynamics and hydro-climatic factors was systematically explored at catchment and pixel scales, which was vital for water resource management and determination of appropriate area for the oases in the endorheic basin.

The objectives of this study were to (1) detect the spatio-temporal variations of vegetation cover in the downstream area of the HRB during 2000-2015, (2) determine the spatio-temporal patterns of the relationships between vegetation dynamics and hydro-climatic factors, and (3) discuss the effects of the water diversion project on vegetation dynamics in the study area.

\section{Materials and methods}

\subsection{Study area}

The downstream area of the HRB is located in Inner Mongolia, Northwest China $\left(100^{\circ} 00^{\prime}-101^{\circ} 30^{\prime} \mathrm{E}, 41^{\circ} 00^{\prime}-42^{\circ} 30^{\prime} \mathrm{N}\right)$ (Fig. 1). The area has a continental arid temperate climate with an average annual precipitation of $34 \mathrm{~mm}$ and an average annual potential evaporation of $3220 \mathrm{~mm}$. The average annual temperature is $9.0^{\circ} \mathrm{C}$, with the highest temperature of $41^{\circ} \mathrm{C}$ in July and a lowest of $-36.4{ }^{\circ} \mathrm{C}$ in January. The lower reach of Heihe River branches into two rivers at Langxinshan (LXS), which are the East River and the West River. The two rivers ultimately flow into the EJL and the WJL, respectively. However, the two lakes dried up in 1992 and 1961, respectively, due to huge water consumption along the river by human activities. The Ejina oasis, at the downstream area of HRB, encompassed by peripheral desert regions, including sand deserts and the Gobi, is distributed along the rivers on the alluvial fan. The predominant natural vegetation is Populus euphratica, Tamarix ramosissima, and Sophora alopecuroides. Sparse vegetation, including Nitraria tangutorum and Haloxylon ammodendron, also exists in the desert regions (Zhang et al., 2011). In this study, the EJL was separated from the downstream area of HRB, and the remaining part was called the Ejina oasis.

\subsection{Data sources}

NDVI is the normalized reflectance difference between the visible red and near infrared bands (Rouse et al., 1974). It is recognized as an indicator of vegetation coverage and greenness, and has been commonly used for spatial vegetation assessments (Kawabata et al., 2001). The Moderate Resolution Imaging Spectroradiometer (MODIS) maximum value composite (MVC) value NDVI with resolutions of 250-meter and 16 -day was used to evaluate surface vegetation conditions. These MODIS vegetation index data (MOD13A1) were derived from the Earth Observing System (EOS) Terra MODIS surface reflectance for the period of 2000-2015. The MVC method was used to minimize atmospheric effects, solar zenith angle effects, scan angle effects and cloud contamination. In this study, monthly NDVI was calculated by the MVC method.

Land use and cover data of three years (1990, 2000, and 2010) were obtained from the Institute of Remote Sensing and Digital Earth, Chinese Academy of Sciences. These maps were derived from Landsat remote sensing images and the Chinese Huan Jing ( $\mathrm{HJ}$ ) satellite with a ground resolution of $30 \mathrm{~m}$. The algorithm of hierarchical classification was employed to follow step-by-step procedures that effectively controlled classification quality. The independent validation indicated that the overall accuracy reached 86\% (Zhang et al., 2014). Land use was divided 


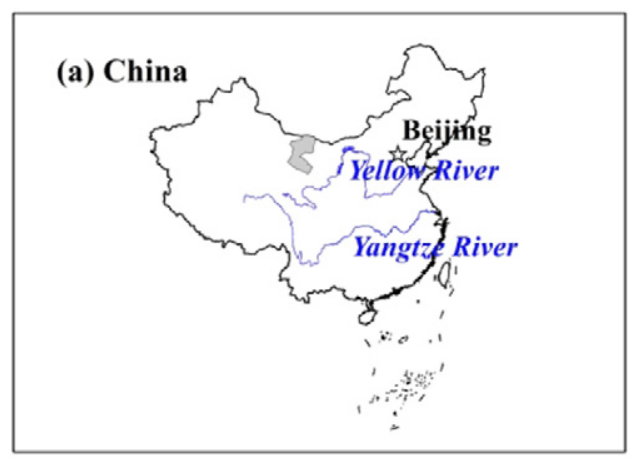

\section{(b) Heihe River Basin}

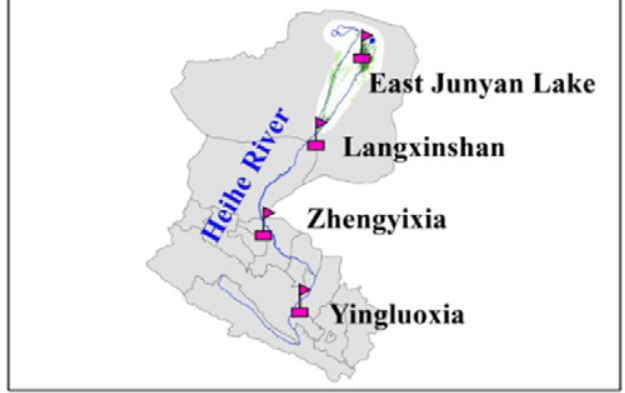

(c) Study area in the lower Heihe River Basin

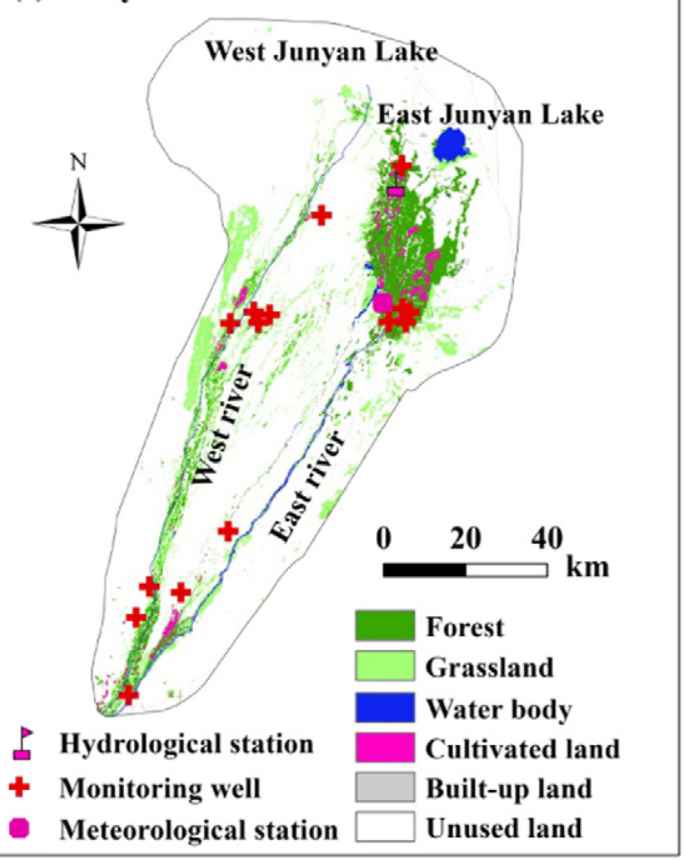

Fig. 1. The location and land uses of the study area in the downstream area of the Heihe River Basin (HRB), China.

into six categories, including forest, grassland, cultivated land, water body, built-up land, and unused land. The water body was further divided into flood land, lake and swamp, and the unused land was further divided into sandy land, saline land, Gobi and bare land in the area around EJL.

The geographic data, including the locations of hydrological stations, the basin boundary, rivers and lakes, were downloaded from the Cold and Arid Regions Science Data Center at Lanzhou (http://westdc. westgis.ac.cn/). The river flow data during 1961-2014 at the Yingluoxia (YLX), Zhengyixia (ZYX), LXS and EJL hydrological stations were collected from the Heihe River Bureau of the Yellow River Conservancy Commission. The YLX is the dividing point between the upstream and midstream stretches, and ZYX is the dividing point between the midstream and downstream stretches. The LXS and EJL stations are the inlet of Ejina oasis and EJL, respectively. The meteorological data (i.e., precipitation and temperature) during 1961-2014 were obtained from the National Meteorological Center, China Meteorological Administration. Monthly water table depth data at 14 monitoring wells distributed along the East and West River were collected from the Ejina Water Affairs Bureau for the period of 1988-2012. The area of EJL during 20042012 was obtained from Si et al. (2015).

\subsection{Data analyses}

Average monthly NDVI data from April to October were defined as the growing season NDVI of each year. To detect the inter-annual variations of NDVI and hydro-climatic variables (precipitation, temperature, river flow and water table depth) during 2000-2015 in the study area, the linear regression between variables and year was used to determine the slope and significance of change. Similar analysis was conducted at the pixel scale to detect the spatial distribution of changing slope and significance of NDVI. Analysis of variance (ANOVA) was applied to evaluate the differences in NDVI between different distances away from the river bank, and obtain the gradient distribution of NDVI.

The Pearson correlations analyses between NDVI and hydro-climatic variables were conducted at catchment and pixel scales. The correlation coefficient $(r)$ and significance $(p)$ were used to determine the degree of correlation between the two variables. The correlations at catchment scale were obtained by calculating on a per-pixel basis and then aggregated in the study area. During aggregating the data, the pixel cell was treated in isolation and the spatial autocorrelation was not taken into account, which was a simple way to detect the relationships between vegetation dynamics and hydro-climatic variables and widely used in previous studies. To further improve the trust of significant/nonsignificant results, the autocorrelation needs to be taken into account. The correlation between groundwater and river flow at the catchment scale was also analyzed. Furthermore, the linear regression analysis was used to determine the quantitative relationship between catchment NDVI and river flow, and those between NDVI and water table depth as well as between water table depth and river flow. The coefficient of determination $\left(R^{2}\right)$ and significance of the regression equation were obtained.

\section{Results}

\subsection{Changes of climatic and hydrological variables}

Fig. 2 illustrates the inter-annual variations in precipitation, mean temperature, river flow at YLX station, river flow difference between YLX and ZYX stations, river flow at LXS and EJL stations, and average catchment water table depth in the study area. Annual precipitation had no significant increase before $\left(0.19 \mathrm{~mm} \mathrm{yr}^{-1}, p=0.54\right)$ and after $2000\left(0.03 \mathrm{~mm} \mathrm{yr}^{-1}, p=0.97\right)$, with the mean value of $35.8 \mathrm{~mm}$ and $29.3 \mathrm{~mm}$, respectively (Fig. 2a). Mean annual temperature increased significantly during $1961-1999\left(0.05{ }^{\circ} \mathrm{C} \mathrm{yr}^{-1}, p<0.01\right)$ with the mean value of $8.6{ }^{\circ} \mathrm{C}$, whereas the increase was not significant after 2000 $\left(0.03{ }^{\circ} \mathrm{C}^{-1}, p=0.21\right)$ with the mean value of $9.9^{\circ} \mathrm{C}$ (Fig. $\left.2 \mathrm{~b}\right)$. In general, the climate tended to be warmer and drier after 2000.

The annual river flow at YLX showed greater increasing during 2000-2014 $\left(0.44 \times 10^{8} \mathrm{~m}^{3} \mathrm{yr}^{-1}\right)$ than that before $2000(0.06$ $\left.\times 10^{8} \mathrm{~m}^{3} \mathrm{yr}^{-1}\right)$, with the mean value of $18.19 \times 10^{8} \mathrm{~m}^{3}$ and 15.76 $\times 10^{8} \mathrm{~m}^{3}$, respectively (Fig. 2c). The mean annual river flow difference between YLX and ZYX was $7.76 \times 10^{8} \mathrm{~m}^{3}$ and $5.73 \times 10^{8} \mathrm{~m}^{3}$ during 2000-2014 and before 2000, with the increasing rate of 0.09 


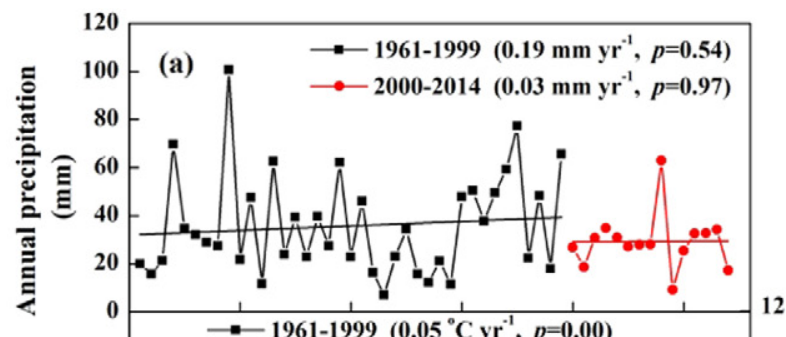

(b)
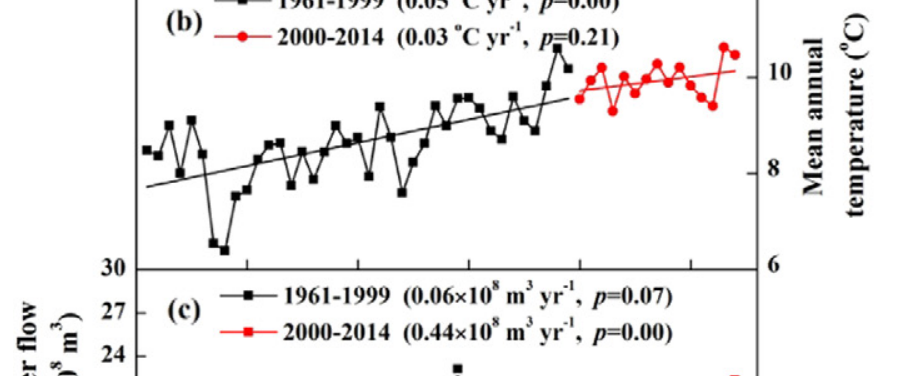

(e) - LXS 1988-1999 $\left(-0.30 \times 10^{8} \mathrm{~m}^{3} \mathrm{yr}^{-1}, p=0.15\right)$

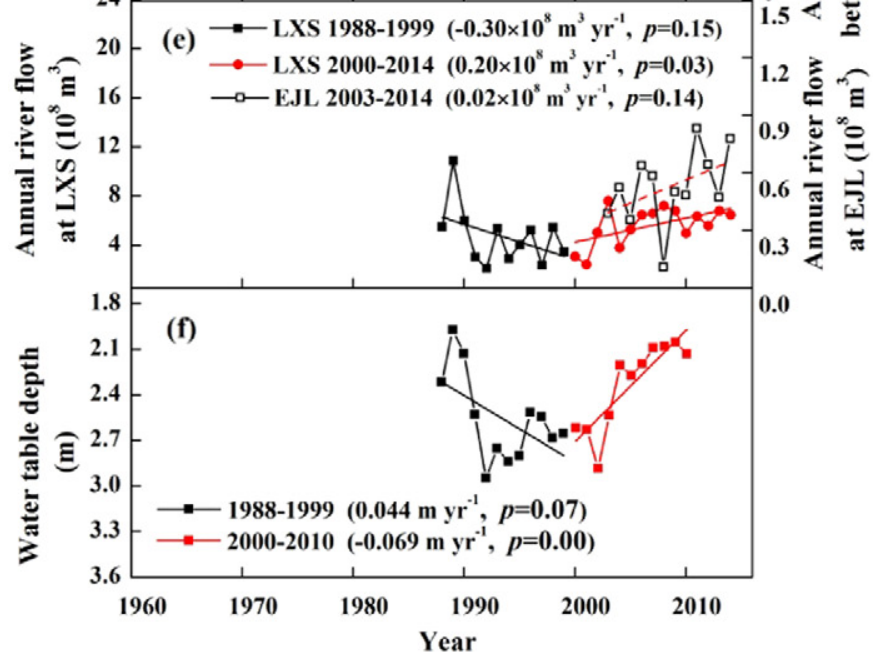

Fig. 2. Inter-annual variations of (a) precipitation, (b) mean temperature, (c) river flow at Yingluoxia (YLX) hydrological station, (d) river flow difference between Yingluoxia (YLX) and Zhengyixia (ZYX) hydrological stations, (e) river flow at Langxinshan (LXS) and East Juyan Lake (EJL) hydrological stations, and (f) average catchment water table depth in the study area. The ecological water diversion project (EWDP) was carried out since 2000.

$\times 10^{8} \mathrm{~m}^{3} \mathrm{yr}^{-1}$ and $0.14 \times 10^{8} \mathrm{~m}^{3} \mathrm{yr}^{-1}$, respectively (Fig. 2d). During 1961-1999, the annual river flow at LXS decreased with the mean value of $4.49 \times 10^{8} \mathrm{~m}^{3}$, and it subsequently increased with the mean value of approximately $5.44 \times 10^{8} \mathrm{~m}^{3}$ as the EWDP carried out in 2000. The annual river flow at EJL increased during the period of 2003-2014 with the mean value of $0.53 \times 10^{8} \mathrm{~m}^{3}$ and changing rate of $0.02 \times 10^{8} \mathrm{~m}^{3} \mathrm{yr}^{-1}$ (Fig. 2e). Water table depth decreased dramatically during the period of 1988-1999, and it rose approximately $0.5 \mathrm{~m}$ from 2000 to 2010 (Fig. 2f).

\subsection{Land use and cover change}

In the study area of the lower HRB, the main land use type was unused land, grassland, and followed by forest, cultivated land, water body and built-up land. In 2000, the area of above six land use types was $8512.70,793.05,719.17,107.98,23.19$ and $20.13 \mathrm{~km}^{2}$, respectively. Fig. 3 shows the land use change during the period of 1990-2010. From 1990 to 2000, forest, grassland and water body decreased by $5.41 \%$, $13.11 \%$ and $63.57 \%$, respectively, whereas cultivated land, built-up land and unused land increased by $2.04 \%, 119.30 \%$ and $2.26 \%$, respectively. From 2000 to 2010, unused land decreased by $1.31 \%$, while the other land use increased by $1.37 \%, 1.15 \%, 308.26 \%, 4.46 \%$ and $80.92 \%$ for forest, grassland, water body, cultivated land and built-up land, respectively. The area of water body increased by over three times.

Fig. 4 shows the land use around the EJL in 1990, 2000 and 2010. The areas of grassland, flood land and swamp decreased from 1990 to 2000, and subsequently they increased after 2000. There was no forest in 1990 and 2000, and it remarkably appeared in 2010 with the area of $0.59 \mathrm{~km}^{2}$. The areas of sandy land, Gobi and saline land increased from 7.24, 52.77 and $10.34 \mathrm{~km}^{2}$ in 1990 to $9.94,53.04$ and $48.28 \mathrm{~km}^{2}$ in 2000, and subsequently decreased to $9.53,52.33$ and $2.86 \mathrm{~km}^{2}$ in 2010 , respectively. The area of EJL dried up before 2000 and it gradually enlarged to $36.4 \mathrm{~km}^{2}$ in 2010 with the area fluctuant at $38 \mathrm{~km}^{2}$ (Fig. 4b).

\subsection{Temporal-spatial variations of NDVI}

Fig. 5 represents the temporal variations of mean growing season NDVI during 2000-2015 in Ejina oasis and the EJL. The mean growing season NDVI increased significantly in Ejina oasis $(p<0.01)$ and the EJL $(p<0.01)$ with the rate of $0.002 \mathrm{yr}^{-1}$ and $0.013 \mathrm{yr}^{-1}$, respectively. Fig. 6 shows the spatial pattern of NDVI change during the period of 2000-2015. The result indicated that the greening trend was evident in the study area. Both the upstream and downstream areas of the East River and midstream area of the West River showed an increasing trend of NDVI, especially around the EJL. However, a decreasing trend of NDVI was found along both the upstream and midstream areas of the West River, and midstream and downstream areas of the East River as well as the heart of Ejina oasis (Fig. 6a). The areas with a significantly increasing and decreasing trend of NDVI reached $2596.44 \mathrm{~km}^{2}$ and $290.00 \mathrm{~km}^{2}$, accounting for $25.57 \%$ and $2.86 \%$ of the study area, respectively ( $p<0.05$ ) (Fig. 6a). The mean changing slopes of NDVI were $0.003 \mathrm{yr}^{-1}$ and $-0.002 \mathrm{yr}^{-1}$ for the significantly increasing and decreasing areas with the range of $0.0002-0.0505 \mathrm{yr}^{-1}$ and -0.0157 to $-0.0002 \mathrm{yr}^{-1}$, respectively (Fig. $6 \mathrm{~b}$ ).

The average annual maximum NDVI was determined for every $0.25 \mathrm{~km}$ interval from the river bank, to explore the gradient

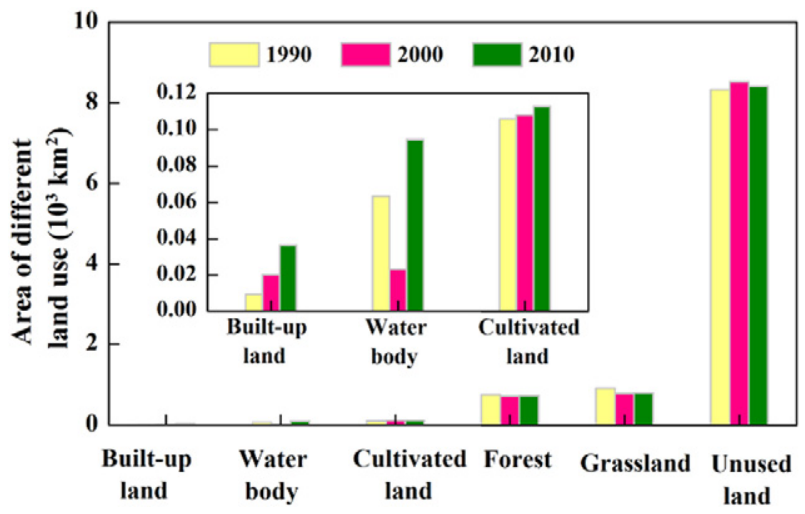

Fig. 3. Land use change during 1990-2010 in the study area. 


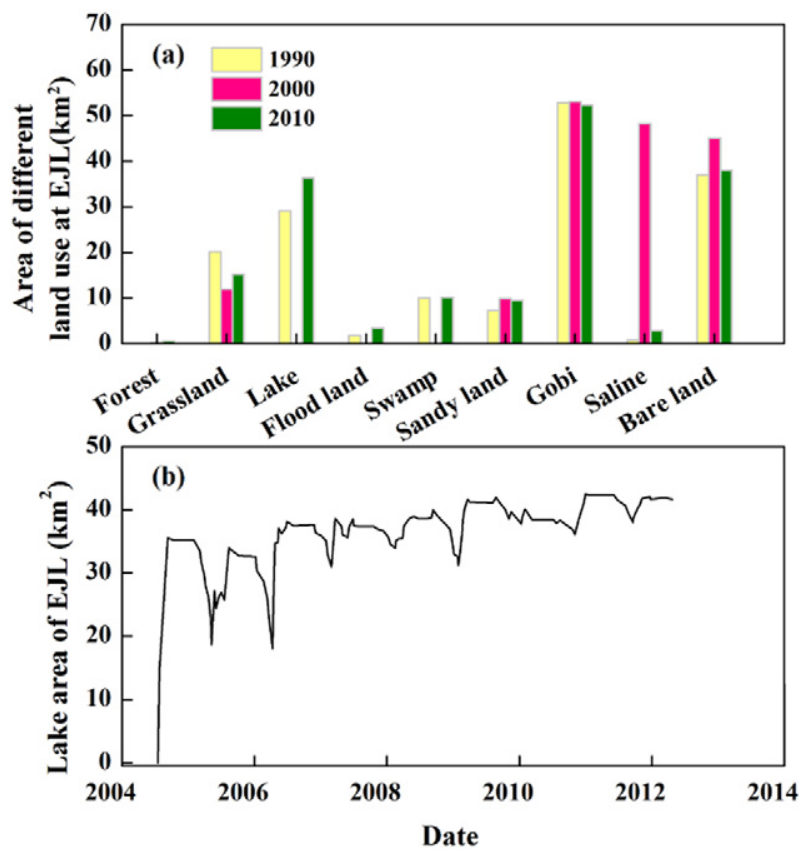

Fig. 4. Land use change around the East Juyan Lake (EJL) during 1990-2010 and variation of lake area during 2004-2012. The EJL dried up in 1992 and recovered gradually after the EWDP since 2000.

distribution of NDVI away from the river bank (Fig. 7). The mean NDVI along the river decreased with increasing distance from the river bank, and decreased significantly from 0.16 at distance of $0.25 \mathrm{~km}$ to 0.15 at distance of $1 \mathrm{~km}(p<0.05)$. With the distance increased to $2 \mathrm{~km}$, the mean NDVI decreased to 0.13 , and subsequently there was no significant difference of NDVI beyond $2 \mathrm{~km}$ distance. Therefore, the oasis mainly concentrated within $2 \mathrm{~km}$ distance from the river bank.

\subsection{Relationships between NDVI and hydro-climatic factors}

At the catchment scale, considering the lagged response of NDVI to precipitation, temperature and river flow, correlation analyses were conducted between each growing season NDVI and the antecedent annual hydro-climatic factors. Table 1 shows the relationship between growing season NDVI and the three hydro-climatic factors of the current year (0-year lag), the antecedent one year (1-year lag), the antecedent two year (2-year lag) and the antecedent three year (3-year lag). The results showed that the growing season NDVI was not significantly correlated with both precipitation and temperature, whereas it increased significantly with the river flow of the antecedent one year at the

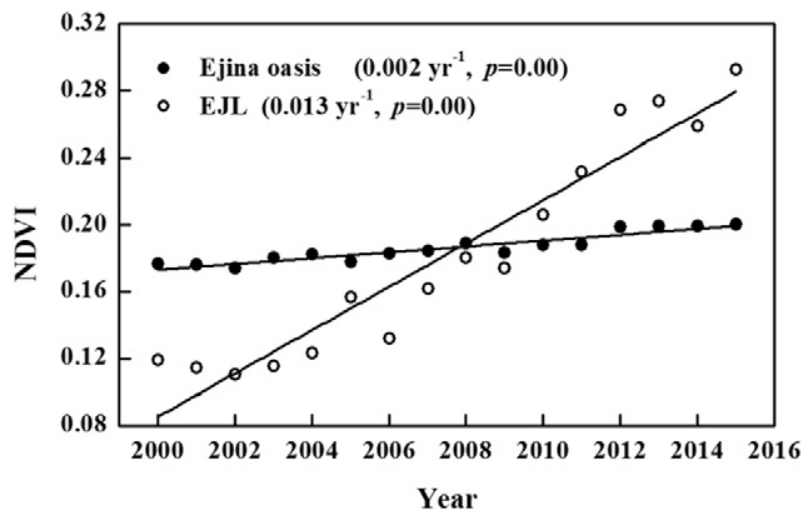

Fig. 5. Variation of growing season (April to October) NDVI at Ejina oasis and EJL during 2000-2015.
Ejina oasis $\left(y=0.005+0.162 x, R^{2}=0.52, p<0.01\right)$ and EJL $(y=$ $0.184+0.108 x, R^{2}=0.30, p<0.05$ ) (Fig. 8). The lag-time effect of the river flow on the vegetation cover was 1 year.

At the pixel scale, Fig. 9 shows the spatial distribution of relationships between NDVI and precipitation, temperature and river flow. The result indicated that the NDVI was significantly positive with precipitation in only $0.65 \%$ of the study area (Fig. 9a). The area where there was significantly positive relationship between NDVI and temperature accounted for approximately $17.40 \%$ of the study area (Fig. 9b). NDVI was significantly positive with river flow in approximately $7.14 \%$ of the study area, which was mainly distributed along the East and West River and EJL (Fig. 9c).

The water table depth decreased significantly with the river flow of the current year $\left(y=-0.09 x+2.92, R^{2}=0.42, p<0.01\right)$ and antecedent one year $\left(y=-0.10 x+2.96, R^{2}=0.51, p<0.01\right)$. This result is powerful to explain the one year lagging effects of river flow on plant NDVI responses. Fig. 10 presents the growing season NDVI and the corresponding water table depth of the 14 monitoring sites. The result showed that NDVI was dependent on water table depth. NDVI was $>0.10$ for water table depth between $1.8 \mathrm{~m}-3.5 \mathrm{~m}$ and $5.5 \mathrm{~m}-6.5 \mathrm{~m}$. This result indicated that the higher NDVI was corresponding to water table depth between $1.8 \mathrm{~m}$ and $3.5 \mathrm{~m}$ for grassland and shrub, and water table depth between $5.5 \mathrm{~m}-6.5 \mathrm{~m}$ was suitable for species with long root system such as $T$. ramosissima.

Table 2 shows the relationship between growing season NDVI and average water table depth in specific site. The result indicated that the relationship between them varied for different wells. The growing season NDVI was negative with water table depth in seven sites, and nonsignificant positive with water table depth in seven sites with NDVI usually $<0.10$. The negative correlation was significant in four sites (N01, N25, N26 and N27) $(p<0.05)$. Linear regression equations between NDVI and water table depth were obtained at the sites of N25 and $\mathrm{N} 26\left(y=-0.076 x+0.524, R^{2}=0.72, p<0.01\right)$, and N01 and N27 $\left(y=-0.045 x+0.272, R^{2}=0.55, p<0.01\right)$.

\section{Discussion}

\subsection{Influencing factors of vegetation dynamics}

Effects of climatic factors on vegetation dynamics were spatially variable, and depended on scale (Liu et al., 2017). Precipitation had little effect on NDVI neither at the catchment scale nor the pixel scale (Fig. 9a and Table 1). This result was different from Kawabata et al. (2001) who found that the decreased annual precipitation could reduce NDVI values remarkably in some arid and semi-arid areas in the Southern Hemisphere during the period of 1982-1990. There was no correlation between NDVI and temperature at the catchment scale, however at the pixel scale, there was approximately $17 \%$ of the study area where the NDVI was significantly positive with temperature (Fig. 9b). The increased temperature stimulated vegetation growth by increasing growing season length and promoting photosynthesis (Slayback et al., 2003). In contrast, Duan et al. (2011) found that the regions with lack of water showed significantly negative correlation between NDVI and annual average temperature, as the higher temperature increased evapotranspiration and the insufficient water limited the growth of plants. Increasing in precipitation associated with higher temperature tended to increase ecosystem productivity and resulted in terrestrial carbon uptake (Nemani et al., 2003).

The river flow positively affected NDVI especially in the areas near the river bank (Fig. 9c), which was evident for the endorheic basin in arid area (Kong et al., 2009). In this study, river flow had a positive influence on NDVI within approximately $2000 \mathrm{~m}$ distance from the river bank (Fig. 7). However, the study in the same area by Guo et al. (2009) indicated that plants grew rapidly in 100-400 m distance away from the river bank after watering, and the incidence of watering on vegetation reached the distance of only $1000 \mathrm{~m}$. Different influencing 


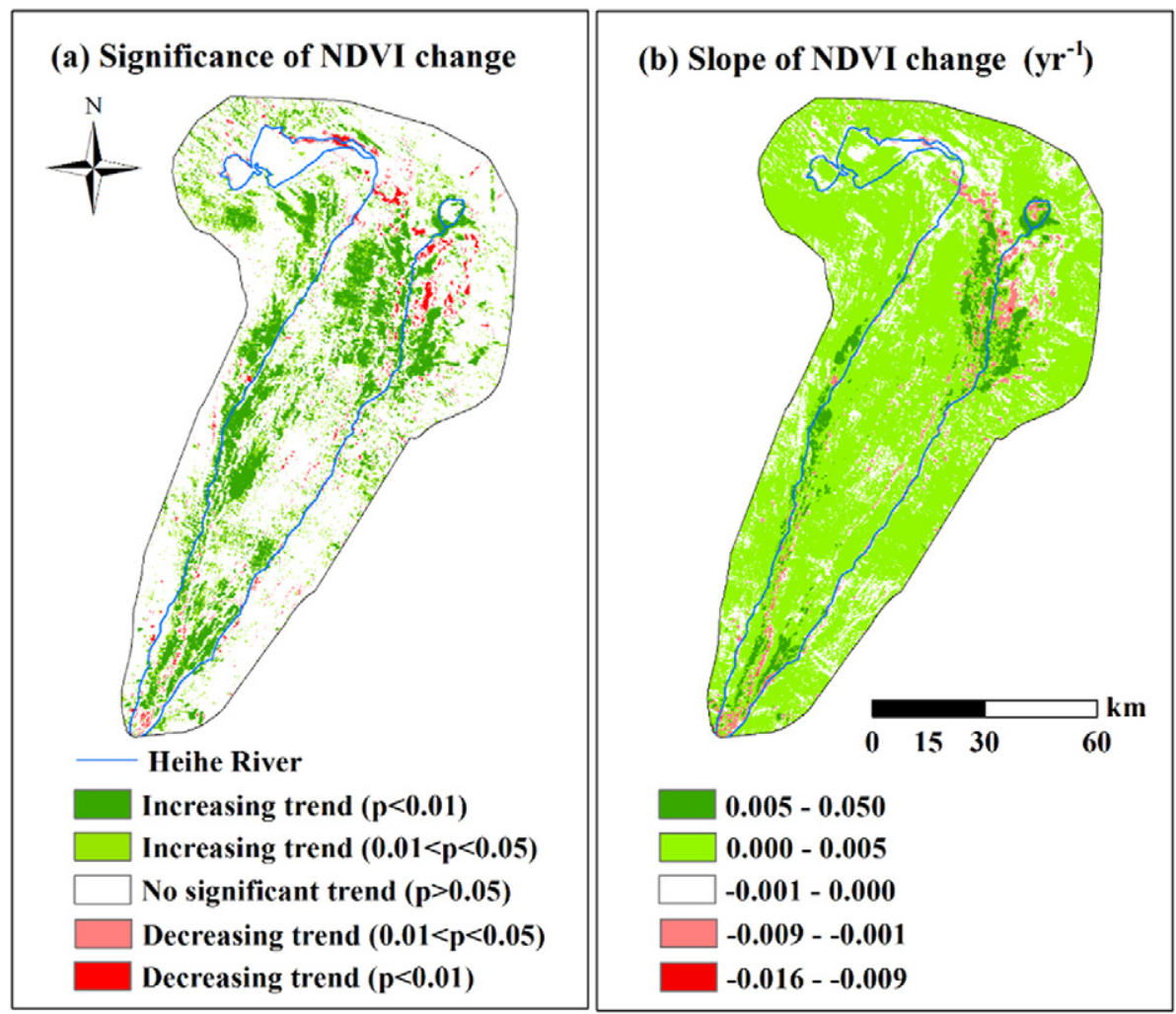

Fig. 6. Significance and slope of change in growing season NDVI during 2000-2015 in the study area.

distance of water delivery on vegetation was mainly attributed to the watering volumes and intervals. It was showed that the influencing distance extended from $570 \mathrm{~m}$ after the first watering to $4022 \mathrm{~m}$ after 12 times of watering in the Tarim River Basin which was the largest endorheic basin of China (Chen et al., 2015). Furthermore, river flow had a 1 year lag-time effect on the vegetation cover during 2000-2015 (Table 1). River flow was effective for raising the local water table and promoting plant growth. The recovery of groundwater recharged by river flow needed a period of time, and the river flow of both the current year and antecedent one year had significantly positive effect on rise of catchment water table depth. Therefore, the increased water table produced a good condition for the vegetation.

The relationship between NDVI and water table depth also proved the effect of groundwater on vegetation growth. Water table depth was the main factor restricting the distribution patterns of groundwater-dependent vegetation in the Ejina oasis (Zhu et al.,

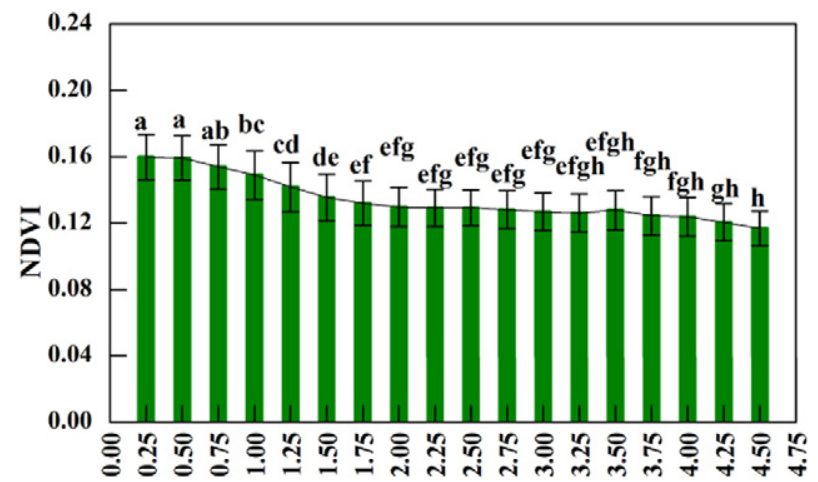

Distance away from the river $(\mathrm{km})$

Fig. 7. The average annual maximum NDVI during 2000-2015 away from the river bank in the study area. The error bars stand for standard deviation, and same lowercase letters indicate no significant differences.
2012). NDVI was larger at the water table depth of 1.8-3.5 $\mathrm{m}$ than that of $1-1.7 \mathrm{~m}$ and 3.6-4.5 (Fig. 10), and the water table depth had significantly negative effect on NDVI at the depth of 1.5-3.5 m Table 2. Chen et al. (2015) found that the appropriate ecological water table depth was probably 2-4 $\mathrm{m}$ in the lower reaches of the Tarim River Basin with achievement of maximum species diversity. Water table depth could affect the soil moisture and salinity, which were closely related to the growth of vegetation (Ye et al., 2009). The suitable water table depth for vegetation growth was between 1.8 and $3.5 \mathrm{~m}$ in this study. However, the larger NDVI also appeared at the water table depth between 5.5 and $6.5 \mathrm{~m}$ for some drought-tolerant trees and shrubs such as T. ramosissima with long root system to reach the deep water table and maintain their survival. Similar result was found by Jobbagy et al. (2011) that the presence of well-developed Prosopis flexuosa woodlands relied on regional groundwater with depth of 6.5 to $9.5 \mathrm{~m}$ in the Monte Desert region of the south America. Therefore,

Table 1

Pearson correlation coefficients $(r)$ and two-tailed significance test values $(p)$ between growing season NDVI and precipitation, temperature and river flow for different time lags at Ejina oasis and East Juyan Lake in the study area.

\begin{tabular}{lllllll}
\hline $\begin{array}{l}\text { NDVI and hydro-climatic } \\
\text { factors }\end{array}$ & Area & & $\begin{array}{l}\text { 0-year } \\
\text { lag }\end{array}$ & $\begin{array}{l}\text { 1-year } \\
\text { lag }\end{array}$ & $\begin{array}{l}\text { 2-year } \\
\text { lag }\end{array}$ & $\begin{array}{l}\text { 3-year } \\
\text { lag }\end{array}$ \\
\hline NDVI and precipitation & Ejina oasis & $r$ & 0.14 & -0.20 & -0.05 & -0.31 \\
& & $p$ & 0.63 & 0.46 & 0.85 & 0.24 \\
& East Juyan Lake & $r$ & 0.04 & -0.22 & -0.04 & -0.17 \\
& & $p$ & 0.88 & 0.42 & 0.88 & 0.54 \\
NDVI and temperature & Ejina oasis & $r$ & 0.29 & 0.19 & -0.05 & -0.36 \\
& & $p$ & 0.30 & 0.49 & 0.85 & 0.17 \\
& East Juyan Lake & $r$ & 0.24 & 0.21 & -0.06 & -0.21 \\
& & $p$ & 0.39 & $\mathbf{0 . 4 4}$ & 0.82 & 0.44 \\
NDVI and river flow & Ejina oasis & $r$ & 0.39 & $\mathbf{0 . 7 5}$ & 0.32 & 0.37 \\
& & $p$ & 0.15 & $\mathbf{0 . 0 0}$ & 0.23 & 0.16 \\
& \multirow{2}{*}{ East Juyan Lake } & $r$ & 0.38 & $\mathbf{0 . 6 1}$ & 0.30 & 0.25 \\
& & $p$ & 0.22 & $\mathbf{0 . 0 4}$ & 0.38 & 0.48 \\
\hline
\end{tabular}

* and $* *$ indicate significance at $p=0.05$ and $p=0.01$ levels, respectively. 


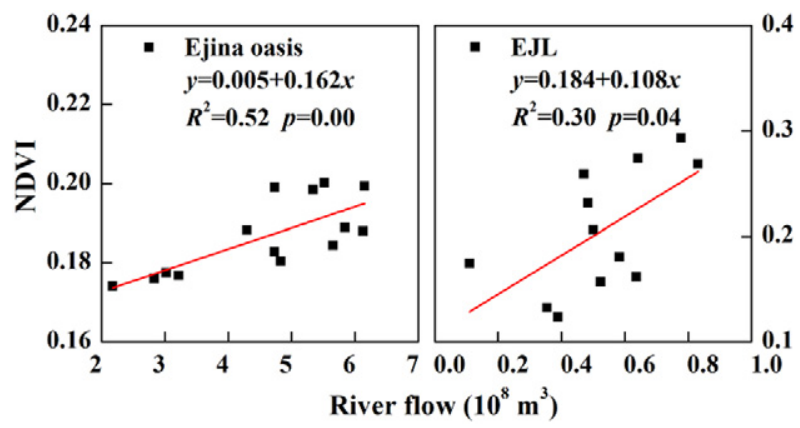

Fig. 8. The correlation between the growing season NDVI and antecedent 1-yr river flow at (a) the Ejina oasis and (b) the EJL. LXS and EJL hydrological stations are the inlet of Ejina oasis and EJL, respectively.

the suitable water table depth for vegetation growth depended on species.

\subsection{Effects of the water diversion project on vegetation dynamics}

Vegetation around the East and West River degraded with decline of water table and shrink of water area in the EJL from 1990 to 2000 before the government started to regulate distribution and management of the water resources in 2000 (Figs. 2 and 3). The eco-environment improved during the period of 2000-2015, and the increase of NDVI also indicated the improved vegetation cover (Fig. 6). Furthermore, the water table rose up (Fig. 2f), and the lake area of EJL gradually recovered (Fig. 4). Therefore, the increased river flow and recovered groundwater due to the EWDP was critical for the improvement of vegetation cover. However, as a result of strong disturbance of human activities, the EWDP also resulted in some negative effects on vegetation cover in some areas.

In order to effectively transport water to downstream area of HRB, the natural river was replaced by artificial main canals as a result of the EWDP, which cut off the hydrological relationship between river flow and groundwater and resulted in some negative effects. First, riparian vegetation degraded along some parts of the river bank (including the upstream and midstream areas of the West River and midstream

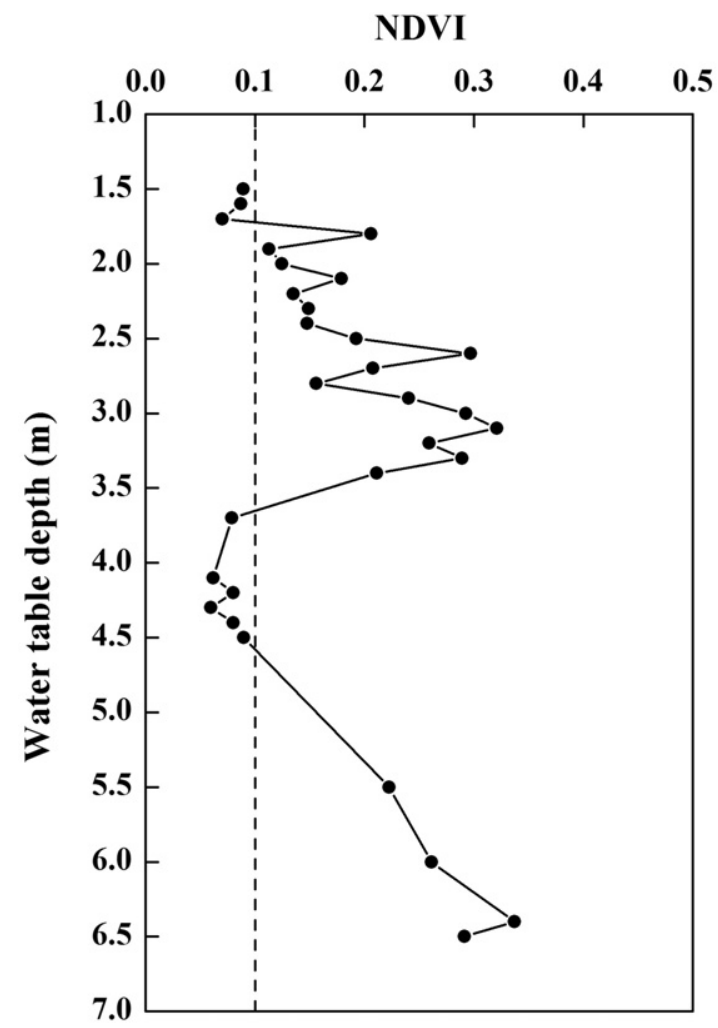

Fig. 10. The growing season NDVI and the corresponding water table depth.

and downstream areas of the East River) as the groundwater was difficult to be recharged by river flow. Second, the terminal lake of EJL recovered and reached up to $36.4 \mathrm{~km}^{2}$ because of the low terrain and efficient water supply channel. In this way, the area of EJL lost the function to indicate the status of ecosystem and environment. Furthermore, the great area of lake resulted in lots of water evaporation as a result of hyper-arid climate condition, accounting for $64 \%$ of the ecological water demand of
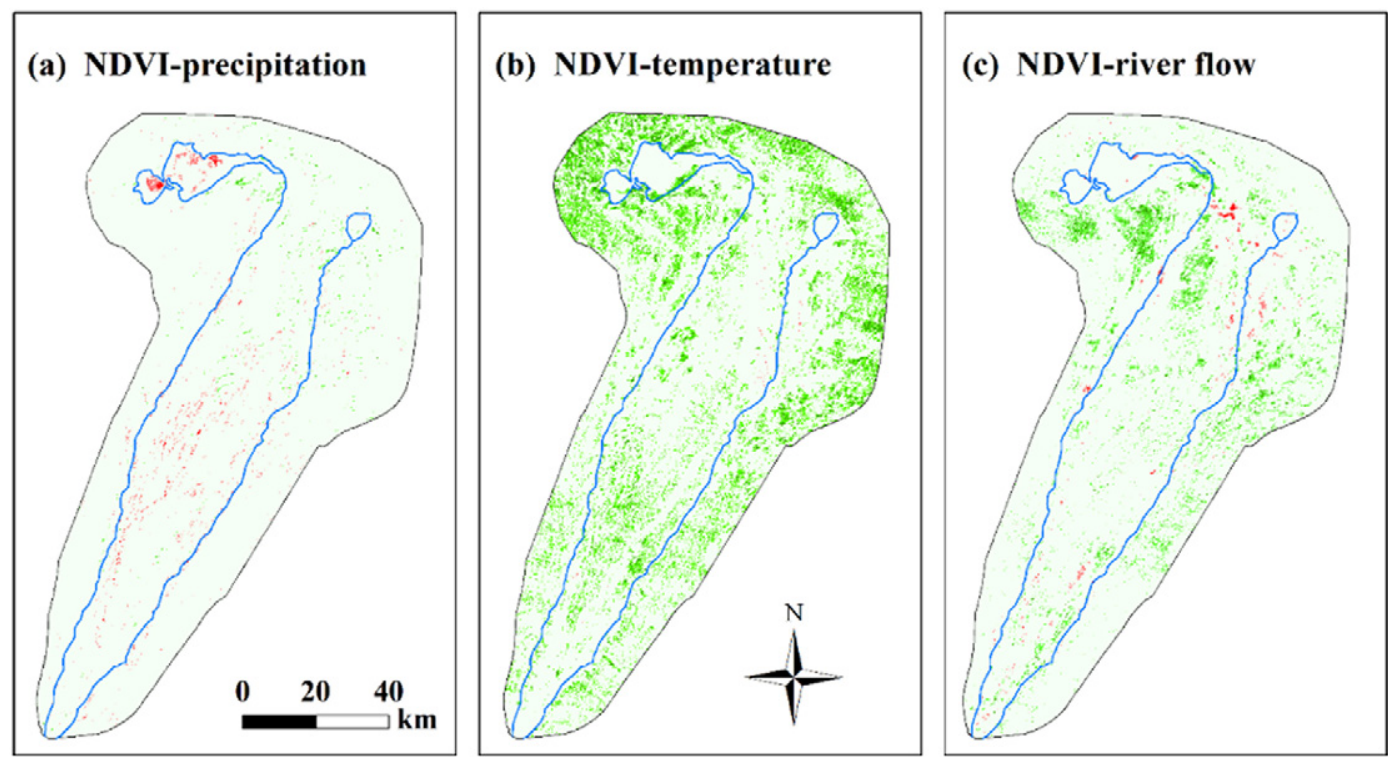

Negative correlation $(\mathrm{p}<\mathbf{0 . 0 1})$

Negative correlation $(0.01<p<0.05)$

Non-correlation $(p>0.05)$

Positive correlation $(0.01<p<0.05)$

Positive correlation $(\mathrm{p}<0.01)$

Fig. 9. The correlation between the growing season NDVI and (a) precipitation, (b) temperature and (c) the annual river flow in the study area. 
Table 2

Pearson correlation coefficients $(r)$ and two-tailed significance test values $(p)$ between growing season NDVI and water table depth in the study area.

\begin{tabular}{|c|c|c|c|c|c|c|c|c|c|}
\hline & $\begin{array}{l}\text { Well } \\
\text { number }\end{array}$ & N01 & N05 & N06 & N25 & N26 & N27 & N33 & N42 \\
\hline \multirow{4}{*}{$\begin{array}{l}\text { East } \\
\text { River }\end{array}$} & \multirow{3}{*}{$\begin{array}{l}r \\
p \\
\text { Land } \\
\text { use }\end{array}$} & -0.725 & 0.09 & 0.52 & -0.67 & -0.82 & -0.71 & 0.14 & -0.54 \\
\hline & & $0.012^{*}$ & 0.81 & 0.10 & $0.03^{*}$ & $0.01^{* *}$ & $0.02^{*}$ & 0.70 & 0.11 \\
\hline & & SG & SG & $\mathrm{S}$ & SS & $\mathrm{S}$ & SS & $\mathrm{BL}$ & SF \\
\hline & \multicolumn{2}{|c|}{ Well number } & N03 & & 13 & N14 & N15 & N16 & N51 \\
\hline \multirow[t]{3}{*}{ West River } & \multicolumn{2}{|l|}{$r$} & 0.18 & & -0.29 & -0.27 & 0.04 & 0.10 & 0.15 \\
\hline & \multicolumn{2}{|c|}{$p$} & 0.69 & & .38 & 0.46 & 0.91 & 0.78 & 0.68 \\
\hline & \multicolumn{2}{|c|}{ Land use } & $\mathrm{BL}$ & B & $\mathrm{L}$ & SG & $\mathrm{BL}$ & SS & $\mathrm{BL}$ \\
\hline
\end{tabular}

BL: Bare land, SG: Sparse grassland, S: Shrub, SS: Sparse shrub, SF: Sparse forest.

$*$ and $* *$ indicate significance at $p=0.05$ and $p=0.01$ levels, respectively.

the terminal lake (Si et al., 2015). It is important to quantify the appropriate lake area and satisfy the water requirement of the surrounding ecosystems.

\subsection{Suggestions and strategies for water resources and ecosystem management}

Ecological water conveyance between the midstream and downstream areas of HRB aimed to promote the suitable water table depth for the growth of riparian desert vegetation and rehabilitate the degraded ecosystems in the downstream areas of HRB. The water delivery was critical to recharge groundwater in the downstream area. The increase of the water table was related to the bulk and duration of water delivery and watering times and intervals (Chen et al., 2015). Therefore, keeping the source of groundwater supply intact should be taken as preferred management option (Kong et al., 2009). However, the water resources contradiction between the midstream and downstream areas has become increasing prominent. As a result of water diversion, river flow was not able to meet the water demand of agriculture in the midstream area and large amount of groundwater was exploited for irrigation, which resulted in notable water table decline in the midstream area. Therefore, to further exert the effects of ecological water delivery and achieve the goal of restoring and protecting the degraded vegetation, it is important to regulate the river flow reasonably and adaptively for ecosystem resilience and functioning, and improve integrated watershed management with consideration of spatio-temporal lagged hydro-ecological connections.

(1) It is vital to carry out the conjunctive use of surface water and groundwater at the basin scale. Understanding the basic mechanism of interactions between surface water and groundwater is needed for effective management of the limited water resource. A coupled surface water and groundwater model should be developed to reallocate water resource between midstream and downstream areas scientifically. A balance between supply and demand for groundwater extraction should be achieved in the basin.

(2) The appropriate area of oasis should be determined according to the available water resource, including area of the irrigated cropland in the midstream and the artificial oasis in the downstream. The irrigation efficiency in the midstream area should be further improved, and the development of agriculture in the downstream area should be limited to guarantee the water consumption for ecological restoration. It is important to define the appropriate recharge area following the relationship between vegetation distribution pattern and river flow.

(3) It is necessary to optimize the water distribution scheme with detailed water resource management planning. Adequate water should be delivered to the downstream area on suitable time to guarantee the water requirement of vegetation at critical growth stages. Furthermore, the ecological water requirement in the downstream area under different scenarios and status of ecosystem should be determiend, including the water requirement for desert riparian vegetation, the restoration of the ecological water table and the terminal lake. In this way, the balance between water supply from the river flow and water requirement in the downstream area can be reached.

\section{Conclusions}

The spatio-temporal variations in vegetation dynamics and their relationships with hydro-climatic factors in the downstream area of HRB were investigated during 2000-2015. Vegetation cover increased significantly, especially along both the up and downstream areas of the East River and midstream area of the West River. At the catchment scale, climatic factors had none-significant effect on NDVI. The antecedent river flow showed significantly positive relationship with NDVI. River flow could affect the vegetation growth for approximately 2000 m distance from the river bank. The lag-time effect of the river flow on the vegetation cover was 1 year. At the pixel scale, the NDVI was significantly positive with river flow and temperature in $7.14 \%$ and $17.40 \%$ of study area, respectively, whereas only $0.65 \%$ of study area showed significantly positive relationship between NDVI and precipitation. Vegetation grew well at the water table depth between 1.8 and $3.5 \mathrm{~m}$, and vegetation cover increased with the decreasing water table depth.

With the water conveyance project commenced in 2000 , the vegetation cover improved evidently in the study area. However, vegetation along some parts of the river bank degraded because the original river channel was replaced by artificial canal in order to make the river flow reach the terminal lake efficiently. The area of terminal lake has increased greatly with lots of water evaporation. Therefore, the water conveyance project should be adjusted and further optimized with consideration of spatio-temporal lagged hydro-ecological connections in the study area. Eco-environment restoration should be conducted in the range of the ecosystem resilience and water carrying capacity to maintain a certain scale of oasis.

This study can be extended to other areas in the world that have had water diversions. The data analysis in this study could be easily replicated, and currently there are many available global satellite imageries. The effects of water diversion on vegetation dynamics and ecosystem restoration could be detected in other similar areas. Therefore, the implications of this work could thus potentially be more global.

\section{Acknowledgements}

This research was financially supported by the National Natural Science Foundation of China (91425301, 91625101 and 91325201), the China Postdoctoral Science Foundation and Chinese Academy Sciences Joint Foundation for Excellent Postdoctoral Fellows (2015LH0038), and the Youth Innovation Promotion Association CAS (2016040). We would like to thank the Linze Inland River Basin Research Station Experimental for field experiment support, and Haiyang Xi for providing the water table depth data. We thank the two anonymous reviewers for their valuable comments which improve the quality of this manuscript.

\section{References}

Barbier, E.B., 2003. Upstream dams and downstream water allocation: the case of the Hadejia-Jama'are floodplain, northern Nigeria. Water Resour. Res. 39 (11):1311. http://dx.doi.org/10.1029/2003wr002249.

Chen, Y., Li, W., Xu, C., Ye, Z., Chen, Y., 2015. Desert riparian vegetation and groundwater in the lower reaches of the Tarim River basin. Environ. Earth Sci. 73 (2), 547-558.

Cheng, G., Li, X., Zhao, W., Xu, Z., Feng, Q., Xiao, S., Xiao, H., 2014. Integrated study of the water-ecosystem-economy in the Heihe River Basin. Natl. Sci. Rev. 1 (3), 413-428.

Duan, H.C., Yan, C.Z., Tsunekawa, A., Song, X., Li, S., Xie, J.J., 2011. Assessing vegetation dynamics in the Three-North Shelter Forest region of China using AVHRR NDVI data. Environ. Earth Sci. 64 (4), 1011-1020. 
Fernandes, M.R., Segurado, P., Jauch, E., Ferreira, M.T., 2016. Riparian responses to extreme climate and land-use change scenarios. Sci. Total Environ. 569-570, 145-158.

Guo, Q., Feng, Q., Li, J., 2009. Environmental changes after ecological water conveyance in the lower reaches of Heihe River, northwest China. Environ. Geol. 58 (7), 1387-1396.

He, C., Zhang, L., Fu, L., Luo, Y., Li, L., DeMarchi, C., 2012. Streamflow allocation in arid watersheds: a case study in Northwestern China. Hydrol. Earth Syst. Sci. Discuss. 9, 8941-8978.

Imentai, A., Thevs, N., Schmidt, S., Nurtazin, S., Salmurzauli, R., 2015. Vegetation, fauna, and biodiversity of the Ile Delta and southern Lake Balkhash - a review. J. Great Lakes Res. 41, 688-696.

James, J.J., Sheley, R.L., Erickson, T., Rollins, K.S., Taylor, M.H., Dixon, K.W., 2013. A systems approach to restoring degraded drylands. J. Appl. Ecol. 50, 730-739.

Jin, X., Schaepman, M., Clevers, J., Su, Z., Hu, G., 2010. Correlation between annual runoff in the Heihe River to the vegetation cover in the Ejina Oasis (China). Arid Land Res. Manag. 24 (1), 31-41.

Jobbagy, E.G., Nosetto, M.D., Villagra, P.E., Jackson, R.B., 2011. Water subsidies from mountains to deserts: their role in sustaining groundwater-fed oases in a sandy landscape. Ecol. Appl. 21 (3), 678-694.

Kawabata, A., Ichii, K., Yamaguchi, Y., 2001. Global monitoring of interannual changes in vegetation activities using NDVI and its relationships to temperature and precipitation. Int. J. Remote Sens. 22 (7), 1377-1382.

King, C.M., 2011. Living with Environmental Change in the Endorheic Oasis Systems of the Northern Sahara. University of Oxford (Ph.D thesis).

Kong, W., Sun, O., Xu, W., Chen, Y., 2009. Changes in vegetation and landscape patterns with altered river water-flow in arid West China. J. Arid Environ. 73 (3), 306-313.

Liu, P., Hao, L., Pan, C., Zhou, D., Liu, Y., Sun, G., 2017. Combined effects of climate and land management on watershed vegetation dynamics in an arid environment. Sci. Total Environ. 589, 73-88.

Lotsch, A., Friedl, M.A., Anderson, B.T., Tucker, C.J., 2005. Response of terrestrial ecosystems to recent northern hemispheric drought. Geophys. Res. Lett. 32 (6), L06705. http://dx.doi.org/10.1029/2004gl022043.

Nemani, R.R., Keeling, C.D., Hashimoto, H., Jolly, W.M., Piper, S.C., Tucker, C.J., Myneni, R.B. Running, S.W., 2003. Climate-driven increases in global terrestrial net primary production from 1982 to 1999. Science 300 (5625), 1560-1563.

Nepal, S., Flügel, W.A., Shrestha, A.B., 2014. Upstream-downstream linkages of hydrological processes in the Himalayan region. Ecol. Process. 3, 19

Patten, D.T., 1998. Riparian ecosystems of semi-arid North America: diversity and human impacts. Wetlands 18 (4), 498-512.
Rouse Jr., J.W., Haas, R.H., Schell, J.A., Deering, D.W., 1974. Monitoring vegetation systems in the Great Plains with ERTS. Goddard Space Flight Center 3d ERTS-1 Symposium. 1. NASA, pp. 309-317.

Schlüter, M., Savitsky, A.G., McKinney, D.C., Lieth, H., 2005. Optimizing long-term wate allocation in the Amudarya River delta: a water management model for ecological impact assessment. Environ. Model. Softw. 20 (5), 529-545.

Si, J., Feng, Q., Yu, T., Zhao, C., 2015. Inland river terminal lake preservation: determining basin scale and the ecological water requirement. Environ. Earth Sci. 73 (7), 3327-3334.

Slayback, D.A., Pinzon, J.E., Los, S.O., Tucker, C.J., 2003. Northern hemisphere photosynthetic trends 1982-99. Glob. Chang. Biol. 9, 1-15.

Wang, P., Zhang, Y., Yu, J., Fu, G., Ao, F., 2011. Vegetation dynamics induced by groundwater fluctuations in the lower Heihe River Basin, northwestern China. J. Plant Ecol. 4 (1-2), 77-90.

Ye, Z Chen, Y., Li, W. Yan, Y, Wan, J. 2009. Groundwater fluctuations induced by ecological water conveyance in the lower Tarim River, Xinjiang, China. J. Arid Environ. 73 (8), 726-732.

Zhang, Y., Yu, J., Wang, P., Fu, G., 2011. Vegetation responses to integrated water management in the Ejina basin, northwest China. Hydrol. Process. 25 (22), 3448-3461.

Zhang, L., Li, X., Yuan, Q., Liu, Y., 2014. Object-based approach to national land cover mapping using HJ satellite imagery. J. Appl. Remote. Sens. 8 (1), 083686. http://dx.doi.org/ 10.1117/1.JRS.8.083686.

Zhang, B., He, C., Burnham, M., Zhang, L., 2016. Evaluating the coupling effects of climate aridity and vegetation restoration on soil erosion over the Loess Plateau in China. Sci. Total Environ. 539, 436-449.

Zhao, Y., Wei, Y., Li, S., Wu, B., 2016. Downstream ecosystem responses to middle reach regulation of river discharge in the Heihe River Basin, China. Hydrol. Earth Syst. Sci. 20 (11), 4469-4481.

Zhu, J., Yu, J., Wang, P., Zhang, Y., Yu, Q., 2012. Interpreting the groundwater attributes influencing the distribution patterns of groundwater-dependent vegetation in northwestern China. Ecohydrology 5 (5), 628-636.

Zhu, Y., Chen, Y., Ren, L., Lü, H., Zhao, W., Yuan, F., Xu, M., 2016. Ecosystem restoration an conservation in the arid inland river basins of Northwest China: problems and strategies. Ecol. Eng. 94, 629-637. 